\title{
THE CHALLENGES OF CROP PRODUCTION IN NIGERIA FOR THE 21ST CENTURY
}

\author{
J. E. Asiegbu \\ Department of Crop Science, \\ University of Nigeria, Nsukka, Nigeria.
}

\begin{abstract}
Before and at the dawn of independence in 1960, Nigeria had a thriving agrarian economy, with food surplus projected for the 70s. The food surplus never happened because of the neglect of agriculture resulting from a thriving oil economy to the extent that presently oil accounts for 94 95\% of Nigeria's foreign exchange earnings.

In the present article, attempts have been made to identify the major challenges and aims of crop and forestry agriculture with a case made for the ways to make crop agriculture to play a robust and more competitive role in the 21 st century.

Nigeria's endowment in crop and environmental resources were shown to be favourable for agricultural development. Ways ahead for agricultural development in the 21 st century were surveyed. Use of proved good quality planting materials based on a good breeding programme which necessitates emergence of indigenous seed firms with commercial orientation, and uses of integrated pest management procedures were strongly emphasized. The right production system and mechanization strategies must be products of research and development based on local conditions and not mere importations based on alien conditions. Agroforestry, with its multiple benefits, was shown to be environmentally friendly and capable of benefiting sustainable production if well programmed into use.

Conservation of Nigeria's fast disappearing wealth of genetic resources as a basis for development of crop idiotypes was seen as a great debt owed to the future generation. Biotechnology, like the Green Revolution of the 20th century, was identified as probably the unfolding revolutionary technology for the 21 st century, that may alter the course of agricultural development, and in which Nigeria must play a competitive role to remain relevant in 21 st century agriculture.
\end{abstract}

\section{INTRODUCTION}

Nigeria had, before independence in 1960 and during early independence, enjoyed a thriving agrarian economy. The growth rate in agricultural production had an edge over population growth and seemed salutary, with the FAO projecting food surpluses in Nigeria for the 1970's. The food surpluses never happened as predicted essentially because the euphoria of the oil boom inadvertently translated into "oil doom" for agriculture within the period. The problem of Nigerian agriculture started with the neglect of the sector, as Nigeria became a mineral oil economy in the 1970s. The rate of population growth outstripped the growth rate in agricultural production, resulting in the dangerously widening gap between food supply and population to be fed. Prior to independence in 1960 agriculture contributed $70 \%$ of Nigeria's Gross Domestic Product (GDP) and by 1966 it contributed only $55 \%$ and the contribution has been since on the downward spiral. From the 1970 s to the present time, mineral oil has accounted for $94-95 \%$ of Nigeria's foreign exchange earning, thus making the contribution of agriculture very negligible. The present scenario is that Nigeria has overdepended on oil economy to the detriment of 
agricultural development and that agriculture should be made to play a more robust role in Nigerian economy as before. It is only necessary that in the 21 st century, agriculture should be made to develop alongside and in complimentary fashion with the oil industry to provide some form of insurance should either sector suffer any unexpected down-turn in a given year or period. Nigeria's precarious over-dependence on oil always comes glaringly to the fore, for example, as in 1981, whenever there is a down-turn in oil prices in international market or when there is problem in crude production.

\section{Aims/Challenges of Crop and Forestry Agriculture in the 21st Century}

The major aims and challenges of the crop and forestry sub-sectors should be to:

1. substantially increase crop yield on per hectare basis;

2. boost production on the overall as to ensure self-sufficiency in the major staples and in the crop-based industrial raw materials;

3. ensure maintenance of high quality of produce;

4. ensure sufficiency in the supply of forestry products (timber, wood and non-timber forestry products);

5. play a competitive role in the generation of GDP and in foreign exchange earning, as was the case before independence and during the early periods of independence.

\section{NIGERIA'S ENDOWMENT IN CROP AND ENVIRONMENTAL RESOURCES}

Nigeria is endowed with rich resources of both crop and environment, which can be harnessed to make Nigeria rich and prosperous. Although essentially tropical, Nigeria enjoys wide variations in climatic conditions due to modifications arising from the wide span of the country, especially latitudinally (from low to high latitudes) and to relief (low to high altitudes). As a result of a combination of the forces of climatic (especially rainfall and temperature), relief and edaphic factors, there are wide diversities in agroecologies with concomitant diversities in the crops that can be grown. The agro-ecoregions span from the Coconut Belt in the coastal region, moving inland and upwards to the north, through the Coastal swamp, the Forest vegetation, The derived savanna, the Sahel and the Monthane vegetation (e.g. Jos Plateau, Mambila highland, Obudu highland and Mandara mountains) with their diverse characteristics and various crop endowments as summarized by Asiegbu (1990). Both cryophilous (temperate) and tropical crops can be profitably exploited. Some important crop resources are summarized below.

\section{A. Food Crops:}

Dioscorea spp., Manihot esculenta, Colocasia esculenta, Xanthosoma mafaffa, Ipomoea batatas, Solanum tuberosum, Zea mays, Oryza sativa, Sorghum spp., Pennisetum spp. Vigna spp. Voandzeia subterrania, Cajanus cajan, Glycine max, Sphenostylis stenocarpa.

Fruits:

Citrus spp., Mangifera indica, Ananas sativus, Carica papaya, Persea gratissima, Psidium guajava, Musa paradisiaca, Musa sapientum.

Vegetables:

Amaranthaceae, Cucurbitaceae, Vernonia amygdelina, (bitter leaf), Lactuca sativa, Botrytis sp, Bota vulgaris, Cucumis sativus, Daucus carota, Allium cepa, Solanum spp, Lycopersicon esculentum, Capsicum spp., Abelmoschus esculenta.

\section{Plantation Cash Crops:}

Theobroma cacao, Elaeis quineensis, Cocos nucifera, Hevea brasiliensis, Camellia sinensis, Coffea spp. Cola spp., Garcinia kola, Timber.

\section{Other Cash/Industrial Crops:}

Gossypium spp., Arachis hypogaea. Triticum spp., Sorghum bicolor, Hordeum vulgare, Nicotiana spp., Saccharum officinarum, 
Corchorus spp.,Zingiber officinale, Ricinus communis, Colocynthis: citrullus, Butyrospermum paradoxum, Sesamum indicum.

\section{Other Tree Crops:}

Pentachletra macrophylla, Irvinga gabonensis, Pterocarpus spp., Xylopia aethiopicum, Dacroydes edulis, Treculia africana.

[Based on Asiegbu (1990).]

Consideration of climatic factors shows that moisture (rainfall) is the only serious constraint to all-year-round cropping since the temperature is never too low or too high to preclude good crop growth, while insolation is considered adequate all through the year. Despite this natural endowment, Nigeria's agriculture is yet to get back to the track of achieving self-sufficiency in crop products. On the overall, the world food production since 1960s has risen faster than the worlds population (Spore, 1998) but in the case of Nigeria, while food demand increases at the rate of 3.5 per cent per annum, food production rate grows at only 1.0 per cent per annum (Federal Ministry of National Planning, 1981). This situation is very unhealthy for Nigeria's economic independence and stability and needs urgent redress.

\section{WAYS AHEAD IN THE 21st CENTURY}

Accelerated development in agriculture and self-sufficiency in crop product will be achieved through expansion of land area under cultivation, use of improved planting materials (seed), matching crop grown to site, optimization of inputs (fertilizer, manure and lime, agrochemicals and irrigation for all-year-round cropping), adoption of appropriate cropping systems, proper crop scheduling to take advantage of unique crop characteristics and weather (rainfall) patterns and pest and disease control.

\section{(i) Expansion of area under cultivation}

Expanding the land area under cultivation is usually a common way of increasing overall production. This is still possible in Nigeria as it has been calculated that 71.2 million hectares of Nigeria's land area is cultivable while only half of it has been put to cultivation (Federal Ministry of National Planning, 1981). Extending areas under cropping has enormous potentials in the north but less so in the south, especially in the east. In this measure, mechanization is very important while use of irrigation is necessary for extending cropping to the drier areas.

Intensification of cropping and measures to increase yields per hectare have become mandatory. Use of improved planting materials and improved management techniques should be employed. It has been observed (Evans, 1993) that improvements in yields of crop plants has been and will continue to be the basis for greater food supply to satisfy human needs.

\section{(ii) Use of improved planting materials}

Bridging the gap between potential and actual productivity is the major objective of research in agriculture, especially in crop production. Although actual productivity is small compared with potential productivity, the level of actual productivity has been increasing. From FAO production Year Book, the global average of actual production of wheat, maize, paddy rice, potatoes and beans gave $2.75,2.41$, 13.44 and 1.39 tones per hectare, respectively, in 1974/76, while Stewart (1970) reported that using intensive production techniques values of $6,12,12,19$ and 3 tones per hectare, which are still lower than the potential values, have been obtained through crop breeding and improved management techniques.

High quality seed is the fundamental basis of high yields in crop production, and is probably the most costly input on a well-organized agriculture. High quality seed is a result of a good breeding programme and requires knowledge, patience and dedication. The Nigerian farmer realizes the importance of good planting material. This is exemplified with $\mathrm{Oba}$ series of hybrid maize ( $\mathrm{Oba}$ $1, O b a 2$, etc.), which despite the high cost of the seed, caught on in the market, but the supply has not been sustained. Breeding aims to combine high yield, high quality (nutrient content and consumerpreferred characteristics), yield reliability and development of pest and disease resistant varieties. It strives to reduce the constraints to yield set by physiological limitations and determines the potential 
above which modification in environmental factors cannot improve yield.

Unfortunately, the present agricultural production in Nigeria is mostly by the small-scale farmers who depend on seed saved from the previous season's crop, unlike in developed agricultural systems where large seed firms produce seed based on scientific principles of breeding and selection with the seeds conforming to set rules and standards.

Seed production is a specialist trade, which requires high level training. This is where graduate farmers will need to play a strong role in Nigerian agriculture. Seeds imported from Europe and other temperate areas cannot be expected to do well in a tropical environment like Nigeria as they have not been bred and selected for the conditions that exist in Nigeria. Seeds must be bred and produced for the local conditions and by the local specialist who know the local problems well.

In addition to the role of the Nationals Seed Service, emergence of indigenous seed firms with commercial orientation will provide a competitive atmosphere for accelerated development in the provision of good quality seed.

\section{(iii) Optimization of inputs}

Maintaining soil fertility and sustainable nutrient supply constitute an overriding constraint to crop production in the tropics (Giller and Willson, 1991). Presently, there is largely "nutrient mining" through intensive cropping as practiced by the traditional low external input (LEI) farmers, resulting in diminishing returns in crop yield with progressive use of the land. The farmers have recognized the efficacy of the use of inorganic fertilizers and are ready for adoption. However, the fertilizers which were heavily subsidized, have suddenly become very costly as a result of Structural Adjustment Progrmme that resulted in the removal of subsidy, making the use of fertilizer unaffordable and even uneconomic for the small farmers. When available, optimal use of these fertilizers, manure and lime should be adapted from research findings to obviate wastes and ensure economic returns. There are a lot of research data on the shelf, which have not filtered to the farmers. A lot of sound practices for maintaining soil fertility and fostering sustainablc agricultural production, especially in small-holder units, include agroforestry, intensive fallowing, green manure, vegetable mulch, stable manure and use of natural symbionts (Muller-Samann and Kotschi, 1994). Intensive fallowing involved varied uses of green manuring techniques. Green manuring with Azolla, $s p p$. (species of water fern) in symbiotic association with blue-green algae, Anabaena azollae, has proved rewarding in the nitrogen economy of paddy soils, giving $30-40 \mathrm{~kg} \mathrm{~N} / \mathrm{ha}$ per harvest (Muller-Samann and Kotschi, 1994).

\section{(iv) Choice of crop production system}

Manintveld (1993) described the major characteristics of three broad agricultural ideologies - Integrated Green Revolution Agriculture (IGRA) characterized by high inputs (pesticides and fertilizer), improved planting materials, high yield, environmentally degrading and high costs; Low External Input and Sustainable Agriculture (LEISA) characterized by low external inputs, use of local unimproved seeds/planting materials, traditional and subsistence in orientation and more environmentally friendly; and Organic Agriculture (OA) characterized by complete reliance on organic manure, no fertilizers and no pesticides, low or no mechanization, low productivity and production, but environmentally friendly. The right production system must maintain the right agro-ecology, reduce energy and resource use thereby resulting in high output: input ratio, reduce nutrient losses (by controlling leaching, run-off and erosion), improve nutrient cycling, preserve natural resources, reduce costs and increase efficiency. Based on the Nigerian situation, there should be no "either/or" with IGRA, LEISA and OA. The acceptable system must be mixes of the good aspects of the three, where the use of improved planting material, economically and environmentally friendly levels of inputs (fertilizers and pesticides) and use of organic manure should be maintained. Low nitrogen and organic matter supplies are particularly serious problems in Nigerian agriculture. Nitrogen fixation is very important in tropical cropping systems (Giller and Wilson, 1991), for example, through the uses of legumes in multiple 
cropping (e.g. crop mixtures), fallows, crop rotation, green manuring, pasture improvement, plantation crops and agroforestry, and is envisaged to play increasing role in Nigerian agriculture.

There should be planned inoculation and use of natural symbionts like vesicular-abuscular mycorrhiza (VA mycorrhiza), legumes $\mathrm{N}$-fixation and non-legumes like blue-green algae of Anabaena and Nostoc species as in rice fields, and other free-living $\mathrm{N}$-fixing organisms. With the use of ethyl methyl sulfonate (EMS) mutagenesis, it has been possible to isolate legumes, e.g. soybean that are supernodulating (produce nodule load excessively higher than the parent) and hypernodulating (Moderately higher nodule load than the parent) mutant (Hansen, 1994), and this holds promise for improving the $\mathrm{N}$ economy and crop yields of crop lands. Mbah (12996) highlighted the feasibility of vermicomposting and the efficacy of biofertilizers in maintaining soil fertility and crop productivity. Organic fertilizer manufacture and use in Nigeria is attracting interest and promises to become important in Nigerian agriculture in addition to its possible spin-off benefits in enhancing environmental sanitation as town refuse, homestead wastes and agro-industrial wastes are cleared for use. Crop/livestock mixture should be increasingly advocated, where an essentially crop farmer also keeps animals (not necessary on a large scale) to take advantages of farmyard manure (stable compost) for manuring crops. Resource management should be made intensive, for example, through recycling sewage water and sludge, urine, kitchen and bathroom water and wood ash (Asiegbu and Ikeogu, 1997).

\section{(v) Mechanization}

Nigeria can no longer rely solely on hoe agriculture to achieve her aspirations in agricultural development in the 21 st century. Some form of mechanization is mandatory to satisfactorily increase the scale and scope of production.

The tedium of hoe culture in crop production has undoubtedly contributed to making agriculture seem a derogatory profession. Innovative tools and light machinery must be introduced to match the production system and farm sizcs. Wholesale importation of the heavy tractor culture has not perfumed the expected magic under the circumstances of the constrained farm sizes and poor resource base of the generality of farmers. Research results tucked away on the shelf should be adapted for use to cope with the local conditions.

The tractor-hiring programme, despite its difficulties and problems and limited successes appears very necessary at least for land preparation. The programme needs to be thoroughly reviewed and strengthened as part of the instrument for attracting and retaining graduate farmers in farming.

\section{(vi) Irrigation for all-year-round cropping}

Irrigation should be aimed at extending the land area under cultivation to the drier areas, supplementing the water needs of crops during the normal growing periods and achieving allyear-round crop production, by growing crops during the dry off-season periods. Temperature and radiation in the whole of Nigeria are adequate for crop growth all through the year if there is sufficient moisture. It will be very rewarding to take advantage of multiple cropping (as is the case with rice) through irrigation. This probably informed the idea for the establishment of the River Basins Development Authority in 1977. The enthusiasm and vision with which irrigation agriculture was conceived through the formation of the River Basin Development Authority did not yield much of the desired results, apparently due to poor implementation and the lack of full preparation for the challenges of irrigation agriculture. The Faculty of Agriculture, University of Nigeria, Nsukka, in collaboration with the Katholieke Universiteit, Leuven, under the UNN/KUL Linkage programme, and with financial support from the European Economic Community, initiated a bold project on All Season Farming Systems Research to generate information on the possibilities for all-year-round cropping practice under Nigerian conditions. The results appeared encouraging but financial 
Table 1. Examples of promising species for production of biological pest control agents.

\begin{tabular}{|c|c|c|c|}
\hline & Plant species & $\begin{array}{l}\text { Part of plant } \\
\text { used }\end{array}$ & Mode of action \\
\hline 1. & Azadirachta indica (neem tree) & $\begin{array}{l}\text { Leaf, seed, bark } \\
\text { stem }\end{array}$ & $\begin{array}{l}\text { Anti-feedant, growth regulating, } \\
\text { repellant, ovicidal. }\end{array}$ \\
\hline 2 & $\begin{array}{l}\text { Ocurus calamus_(sweet flag-an } \\
\text { ornamental) }\end{array}$ & Rhizome & $\begin{array}{l}\text { Pesticidal, anti - feedant, anti - feedant, } \\
\text { anti -- fertility }\end{array}$ \\
\hline 3 & Allium stivum (onion) & Leaf, bulb & $\begin{array}{l}\text { Anti -fungal, anti-feedant, repellant, } \\
\text { control mites. }\end{array}$ \\
\hline 4 & Allium sativum_(garlic) & Leaf, bulb & $\begin{array}{l}\text { Ticks, insects, anti-bacterial, anti } \\
\text { fungal, anti-nematode, anti -- tick } \\
\text { actions, anti-feedant. }\end{array}$ \\
\hline 5 & $\begin{array}{l}\text { Annona reticulata (mustard } \\
\text { apple) }\end{array}$ & $\begin{array}{l}\text { Seed (poisonous } \\
\text { to humans) }\end{array}$ & $\begin{array}{l}\text { Effective in the control of rice field } \\
\text { insects and others. }\end{array}$ \\
\hline 6 & $\begin{array}{l}\text { Chrysanthemum } \\
\text { comerariifolium_(Pyrethrum) }\end{array}$ & Flower & Controls a wide array of insects. \\
\hline 7 & Derris elliptica_(derris) & Root & $\begin{array}{l}\text { Insecticide rotenone for control of } \\
\text { insects and nematodes. }\end{array}$ \\
\hline 8 & $\begin{array}{l}\text { Lantana camara (common } \\
\text { lantana) }\end{array}$ & $\begin{array}{l}\text { Stem, } \\
\text { flower }\end{array}$ & $\begin{array}{l}\text { Control of several pests including } \\
\text { aphids. }\end{array}$ \\
\hline 9 & Ocimum sanctum (holy basil) & $\begin{array}{l}\text { All the plant } \\
\text { parts }\end{array}$ & $\begin{array}{l}\text { Control of fleas, flies, maggots, } \\
\text { mosquitoes, nematodes. }\end{array}$ \\
\hline 10 & Piper niqrum (black pepper) & Fruit & $\begin{array}{l}\text { Anti-fungal, mites and nematode \& } \\
\text { insecticiedal }\end{array}$ \\
\hline 11 & $\begin{array}{l}\text { Zinqiber officinale rhizome } \\
\text { (common ginger) }\end{array}$ & Rhizome & Anti - fungal \\
\hline 12 & muricata & Lea & $\mathrm{C}$ \\
\hline 13 & squamos & Leaf, & ison \\
\hline 14 & tabacum & Whole plant & Cor \\
\hline 15 & Discorea hispoda & Tuber & oison \\
\hline 16 & Gloricidia sepium & Leaf & Insecticidal \\
\hline 17 & frutescens _ (hot & Fruit & Foliar pest \& storage pest. \\
\hline 18 & Spirostachy africana & Sap & $\mathrm{Pe}$ \\
\hline 19 & Pongamia glaba & Leaf & Anti - termite, nematicidal. \\
\hline
\end{tabular}

Based on Ahmed and Stoll (1996)

support has not been sustained. Data from such researches are needed for well-planned irrigation programmes.

The idea of developing the river basins for irrigation is sound and the River Basin Development Authorities should be revamped, revitalized and sustained. Beside reliance on river, streams and boreholes as the sources of water supply for irrigation, "water harvesting" from natural rainfall has been proposed by Asiegbu (1990). By this, run-off water from the high precipitation, which are in excess of evapotranspiration (Wyseure and Asiegbu, 1990), during the rainy season can be impounded for later use during the dry season. It will constitute an excellent form of water-shed management and reduce ecological hazards due to erosion.

\section{(vii) Pests and Diseases control}

It has been estimated that crop losses to pests and diseases in developing countries is about $30 \%$, with losses of up to $50-70 \%$ in tubers and cereal, $40-60 \%$ due to uncontrolled weed growth in maize or $80-100 \%$ in dry land rice in Nigeria (Igwegbe and Ezueh, 1990). Igwegbe and Ezueh (1990) have reviewed the various methods of control of pests and diseases, ranging from physical and mechanical, through biological, cultural, use of agrochemical and use of 
integrated pest management control (IPM) methods. Because of the very high costs in the use of chemical pesticides and the adverse environmental and health implication, less use of danger in the use of BPC agents lies in the overharvesting of the natural resources as is already becoming the case with neem. The use of BPC should be officially recommended with the

Table 2. Examples of important agroforestry tree species

\begin{tabular}{ll}
\hline Species & $N$-fixed (kg N/ha) \\
\hline Acacia specios, e.g. Acacia albida - & - \\
very versatile in use & - \\
senegalensis & - \\
A. arabica & $224-274$ \\
Leucaena leucocephala & $74-548$ \\
L. leucocephala & - \\
Parkia biglobosa & - \\
Butyrospermum parkii & - \\
Sesbania grandifolia & 442 \\
S. cannabina & - \\
S. sesban & $83-109$ \\
S. rostrata & $40-60$ \\
Casuarine equisetifolfa & - \\
Gliricida sepium & Based on Giller and Wilson (1991), and Muller- Samann and Kotschi (1994))
\end{tabular}

synthetic chemical pesticides is advised. The integrated pest management (IPM) approach, which involves such practices as use of resistant crop varieties "clean" cultivation, use of baits and traps and planting of decoy crops (Ahmed and Stoll, 1996) and co-ordinated use of all known practices in an economical and environmentally friendly way, is advocated. The use of biopesticides referred to as botanical pest control (BPC) agents (Ahmed and Stoll, 1996) or agro-botanicals, because of their cheapness, ease of availability and their minimal environmental hazards is presently increasingly advocated. Over 2,400 plant species have been identified for their pesticidal activities and the practice is increasingly gaining popularity. Table 1 summarizes examples of the more promising species in use.

The neem plant, Azadirachta indica is probably the most widespread in use and the most commercialized presently. In India, the relatively affluent and better educated farmers buy the neem and Panqamia glaba cakes and use them for nematode control as they find no other better or equally effective synthetic pesticides. The only appropriate technology for use, and not merely regarded as a traditional and backward practice.

\section{(viii) Agroforestry}

A recent change in thinking has led to the belief that the Green Revolution approach which is characterized by the practice of crop monoculture combined with intensive mechanical tillage, high mineral fertilizer and chemical pesticides, cannot satisfy the aspirations of small holder farmers of conserving and improving fertility of tropical crop land (Janzen, 1973; Igbozurike cited in MullerSamann and Kotschi, 1997). Agroforestry which had been an age-long practice is being rediscovered and developed as being conducive to the peculiar conditions of the tropics.

Agroforestry has been defined variously (Chan Kuo, 1977; Beets, 1989; Budowski, 1981 cited in Budowski, 1981; Young, 1989), It is a technique of land use in which woody perennials are combined with herbaceous crops (food crops and/or pastures) and /or livestock in spatial arrangement, or rotation or both and on which there are both ecological and economic 
interactions between the tree and non-tree components of the system, and in which the objective is sustained optimization of total production per unit area of land (Budowski, 1981 cited in MullerSamann, 1997; Young, 1989 cited in Giller and Wilson, 1991). The system aims to combine high but no-risk production with sustainable production (Budowski, 1981). It involve various subsystems such as agro-silvicultural (mixture of field crop and forest) sylvopastoral (forest and range management), agrosylvopastoral (field crop, forest and range management combined). Agriculture, using honey producing trees, aquaculture, multi-purpose woodlots and alley cropping are other forms of agroforestry.

Agroforestry has the benefits of sustainable production, increase in soil stability, fertility and organic matter content, control of erosion and desertification, nutrient cycling, diversification of farm enterprises, production of food, fuel wood, wood/timber and other economic non-timber forestry products and stabilisation of microclimate, etc. Pure plantation agriculture, e.g., forestry, oil palm, cocoa and rubber plantations are facing serious problems of competition for the land with food crops and buildings. Agroforestry is an adaptation for an intensive and efficient land cultivation, which will ensure that both field crops (food and cash crops), and trees (forest species and plantation tree crops) are grown in efficient mixtures. Forestry species are combined with food crops in a taungya system, while oil palm in lower population is combined with food crops, where the food crop is grown in the alleys formed by rows of the oil palm trees. Shade loving crops like cocoa will also benefit from similar suitable agroforestry arrangement. This ensures that timber, food crops and cash crops are all given adequate consideration in development and exploitation. Table 2 gives examples of good agroforestry tree species that can be adapted for use in agro-forestry mixture with food crops.

\section{(xi) Biotechnology in Nigeria's 21st century agriculture}

The Malthusian theory of survival of the fittest in relation to increase in food supply versus increase in human population failed to occur because of various developmental interventions in agriculture, the more spectacular of which included the industrial Revolution of the 18 th and 19 th centuries and the Green Revolution of the 20 th century. The 21 st century agriculture appears poised to receive a similar boost from the science of biotechnology.

Biotechnology has been defined as any technique that uses living organisms to make or modify products to improve plant or animals and to develop micro-organisms for specific uses (Caves, 1993). Biotechnology broadly consists of the simple long established technologies that are widely and commonly applied by ordinary peoples to the technically sophisticated and more recently developed technologies presently only applicable by specialists (Bunders, Haverkort and Hiamstra, 1996). Biotechnologies developed through formal research according to Broerse and Visser (1996) covers the areas of:

Food processing: fermentation, enzyme technology, monoclonal antibody technology.

Plant nutrition: biofertilizers, biocontrol agents and diagnostics (immuno-assays \& DNA probes).

Germplasm improvement and conservation:

Selection and breeding: Tissue culture, genetic markers, genetic modification, mutation induction, somatic hybridisation and cybridisation.

Reproduction: mass propagation, embryo technology.

Germplasm conservation: tissue culture, isozyme analysis

Genetic engineering, more recently known as the recombinant DNA technology (RDNA), has made possible the production of diseaseresistant and higher yielding specimens which can be mass propagated by cloning using tissue culture techniques (Villaloisos, 1996). By use of molecular markers, scientists can now assess and transfer to crops genes that confer resistance to a wide range of pests and diseases (Bunders, Haverkort and Hiemstra, 1996), giving a faster and 
more precise results than the conventional breeding programmes. Tissue culture has found ready application in mass propagation of identified elite planting materials by cloning. This can be applied in oil palm development where Malaysia, within a space of about 20 years has superseded Nigeria as the highest exporter of palm produce and now accounts for $60 \%$ of the world trade (Onwubuya, 1997). Identified elite oil palm materials of superior genetic constitution and that are adaptable to local conditions can be mass propagated by cloning using tissue culture techniques. Many crops can benefit from this technique. It has been concluded (Juma and Mugabe, 1996) that this nascent field of biotechnology has the potential to alter both the basic parameters of agriculture and the composition and direction of world trade, and therefore, Nigeria and indeed Africa must be competitive in its development to remain relevant in the 21 st century agriculture. There are yet component training needs to satisfy this aspiration.

\section{(x) Agricultural labour supply}

Agriculture has over the years lost most of the able bodied young men to the oil and construction industries. Farming has become unfashionable and derogatory and mostly only old people (men and women) have remained in agriculture. Labour has consequently become very costly and even prohibitive, constraining the area of cultivation a farmer with his family labour can cope with. A radical innovation is called for to reduce reliance on human labour and yet increase the land area under cultivation. Use of traction in the forms of farm animal power and medium level technology implements will help greatly to lessen drudgery and restore respectability to cropping enterprises.

\section{(xi) Matching crop to site}

Matching crop to site is a function of weather (light/radiation, temperature and moisture), crop adaptation and soil type and fertility status. There is a need to match crops to site so that those crops that thrive best in certain ecozones are better exploited in such areas. Radiation (intensity and duration), which is the basis of photosynthesis and consequently yield, varies greatly with different localities, being higher in the higher, than in the lower latitude areas, and therefore results in higher productivity in the higher latitude areas. In Nigeria, radiation varies from 348 to 492 ${\text { cal } \mathrm{cm}^{-2} \text { day }}^{-1}$ (Kassan and Kowal, 1973) compered with 390 to $685 \mathrm{cal} \mathrm{cm}^{-2}$ day $^{-1}$ for the U.S. (Loomis and Williams, 1963) and is considered adequate for all-year-round cropping. However, those that require high light intensity (e.g. cereals) should be better grown in the north while those that require less light intensity (shade loving) are better grown in the south. Exploiting onion for commercial seed or growing tomato is better in the higher latitudes of the north and in the higher altitudes (Jos Plateau, Mambila highlands, Obudu hill) where wide diurnal range in temperature and low night temperature requirements are important for flower induction and fruit set. Hence Kassan and Kowal (1973) reported 162\% higher yield of tomato in the north than in the forest zone.

\section{(xii) Development of Urban and Peri- urban Agriculture}

A new impetus should be given to urban and peri-urban agriculture, especially due to the increasing scarcity of cultivable land (Asiegbu and Ikeorgu, 1997). It will reward urban economies in that, city dwellers can supplement their earnings and contribute part of their household food needs.

It will be recalled that during colonial periods and during early independence, government attitude was hostile to city farming, which was also considered derogatory and unacceptable for one in government service to engage in. This situation should change and is changing as noted by Mougeot (1994). City farming or farming at close quarters is a form of land use system in high population area. It is practised in many countries like India, Indonesia, Malaysia etc. (Jacob and Alles, 1987), and although has long been in practice, has become a new field requiring peculiar research attention for full development. Urban and peri-urban agriculture can be highly commercialised especially in the areas of floriculture (for production of pot plants, cut flowers, lawns) and vegetable production. Hydroponic culture techniques in greenhouses and 
growth structures are possible where full field cultivation is constrained by space and concrete floors. The special attraction lies in its efficient utilisation of space, high yield of high quality produce (Midmore, 1994), health benefits in improving the urban microclimate, recycling of urban waste profitably, ensuring clean urban living and improving the food security and economy of urban dwellers.

\section{(xiii) Forestry development}

Increase in the land area under cultivation has generally meant clearing natural forests for food crop production without attempts at reforestation. Natural regeneration is precluded with little or no fallow periods. Forests are also lost to urbanisation, industrialisation, road construction and buildings. This has led to loss of soil cover, erosion, degradation of croplands, loss in soil fertility, "nutrient mining", loss in germplasm resources and disappearance of many non-timber forest products. Unless for a few aforestation projects in the north of the country, partly aimed at checking desert encroachment, very little attention has been paid to forestry development, judging from the amount usually allocated to it. Only $2 \%$ of $913,073.64 \mathrm{~km}^{2}$ of Nigeria's land area is forest reserve (Ero, 1998).

A good agroforestry programme in which forestry species are grown in compatible arrangements with food and cash crops should be adopted. This will enable otherwise food crop farmers gain the benefit accruing from tree species. Ero (1998) listed examples of indigenous forest species that can be exploited.

\section{(xiv) Development of floriculture}

Crop agriculture in the 21 st century should not strive only to satisfy the needs for food, fibre and industrial raw materials but should also provide for the general leisure and wellbeing of the people through the development of various aspects of floriculture and landscaping provision of lawns, avenues, parks. This requires trained practitioners and general public awareness to turn it into a lucrative regular business.

\section{(xv) Developing Overseas Markets for Indigenous Crop Products}

Many tropical crop products are and can be in high demand in Europe if appropriate market channels are developed. $\Lambda \mathrm{s}$ is the case in some East African countries like Kenya, it will be a rewarding venture to export cut flowers and ornamentals to Europe. Cote d'Ivoire enjoys a thriving export business of pineapple which Nigeria can also do. Pineapple, avocado, banana and now also mango are four major tropical fruits produced in Nigeria which are in very high demand in Europe. Other crops that hold high cash and export potentials but which have not yet been well developed are soybean and sesame. These should be developed while the production of the traditional cash crops of cocoa, oil palm, rubber and cotton should be expanded.

\section{(xvi) Land Tenure}

Land tenure is probably one of the greatest constraints to large-scale crop production, especially in southern Nigeria. The small-holders have only about $0.5-4$ hectares of land for cultivation. There is a threshold level of land holding below which commercial and economic production will not be feasible. Increasing the land holding of the bona fide farmer is a social issue requiring action. It is proposed that an heir who is also a bona fide farmer can only inherit land holding allocated to a bona fide farmer.

\section{(xvii) Genetic Resources Conservation}

Nigeria is blessed with abundant genetic resources which include herbs, shrubs, food trees and timber species, many of which are yet to be collected and put to use as food, pharmaceuticals, industrial materials and gene banks (Okigbo, 1992; Okonkwo, 1998). The forests provide homes for most of the genetic resources, which are disappearing, with the disappearance of forests. Those genetic resources will evidently provide the basis for the development of crop ideotypes. We therefore owe a great debt to the future generation to conserve and develop the rich 
genetic resources.

\section{(xviii) Gender Inequities}

It is widely known that women bear a disproportionately significant burden of food crop production while men are more interested in cash crops. It is the men who benefit from the land tenure system and who are more often considered for loans and subsidies. It should, therefore, be recognised that women are very important stakeholders and therefore discriminatory inequities should be redressed.

\section{(xix) Research and Development}

Research and development should constitute the basis of Nigeria's agriculture in the 21 st century. There is a need for patience and dedication as it usually takes some gestation period for results of agricultural research to be felt in the production system. It is becoming increasingly necessary that the co-operation of social scientists working in a multidisciplinary approach with agricultural scientists must be enlisted early enough from the time of technology design in order to facilitate transfer and satisfactorily asses adoption and impact.

\section{REFERENCES}

Ahmed, S. and Stoll, G. (1996): Biopesticides. In: J. Bunders, B. Haverkort and Hiemstra (eds.). Biotechnology: Building on Farmers' Knowledge. Macmillan Education Ltd.

Anon (1998): Food security: Grasping at straws? Spore: CTA Information for Agricultural Development in ACP Countries.

Asiegbu, J.E. (1990): Crop resources and management in National Development. In: A.I. Ikeme (ed.). The Challenges of Agriculture in National Development. Optimal Computers Solution Ltd. Enugu. p. $198-230$.

Asiegbu, J.E. and Ikeorgu, J.E.G. (1997): Urban, peri-urban and compound enterprises. Invited paper read at the Workshop on Ecoregional Program for the Sub-humid
Tropics of Sub-saharan Africa (EPITA) held at Concord Hotel, Owerri, Imo State, Nigeria. October 6, 1997.

Beets, W.C. (1989): The potential role of agroforestry in ACP states. Publication of the Technical Centre for Agricultural and Rural Co-operation. The Netherlands. $p$. $11-27$.

Broerse, J. E. W. and Visser, B. (1996): Biotechnology: assessing the potential. In: $\mathrm{J}$.

Bunders, B. Haverkort and W. Hiemstra (eds.). Biotechnology: building on the Farmers knowledge. Macmillan Education Ltd. London. p. $131-180$.

Budowski, G. (1981): Agroforestry in Central America. In: DSE (1983). Agroforestry. Proceedings of a seminar held in CATIE Turrialba/Costa Rica. Feb. 23 -- March 3, 1981. Deutsche Stiflung fur Internationale, Entwicklung, Feldafing.

Chan Kuo, P. (1977): Agroforstry: Its concepts and implications of a sound land use goal. Canopy Vol. 3, No. 11. 6-7.

Ero, I.I. (1998): Indigenous plants: Production and utilisation. Invited paper presented at the Inaugural Meeting of the R \& D Team on the Development of National programme on Indigenous Crops and Animals held at the National Centre for Genetic Resources and Biotechnology, Moor Plantation, Ibadan. May 4 - 7, 1998.

Evans, L.T. (1993): Crop Evolution, Adaptation and Yield. Cambridge University Press, London. pp. 500.

Federal Ministry of National Planning (1981): Fourth National Development Plan, 198185. Lagos. Vol. 1. pp. 447.

Giller, L.E. and Wilson, K.J. (1991): Nitrogen Fixation in Tropical Cropping Systems. $\mathrm{CAB}$ International Publication. Wallinford, U.K. pp. 313.

Hansen, A.P. (1994): Symbiotic $\mathrm{N}_{2}$-Fixation of crop Legumes. Margraf Verlag, Weikerscheim, Germany. pp. 248. 
Igbozurike, U.M. (1977): Agriculture at the Cross Roads. University of Ife Press, Nigeria.

Jgwegbe, E.C.K. and Ezueh, M.I. (1990): The role of crop protection in national development. In: A.I. Ikeme (ed.). The Challenges of Agriculture in National Development. Publication of the Faculty of Agriculture, University of Nigeria, Nsukka. pp. $231-263$.

Jacob, V.J. and Alles, W.S. (1987): Kandyan gardens of Sri Lanka. Agroforestry Systems 5: $123-137$.

Janzen, D. H. (1993): Tropical agroecosystem. Science 182: $212-1219$.

Juma, C. and Mugabe, J. (1996): FAO/AGP Programme on Plant Biotechnology Expert Consultation. In: Ceres, No. 153, Vol. 27. No. 3. p. 34.

Kassan, A.H. and Kowal, J.M. (1973): Productivity of crop in the savannah and rainforest zones in Nigeria. Savannah (1): 39 - 49.

Loomis, R. S. and Williams, W. A. (1963): Maximum crop productivity: An estimate. Crop Sci. 3: $67-72$.

Mbah, C.C. (1996): Treater-cassava peel vermicomposts enhanced earthworm activities and cowpea growth in field plots. Resources, Conservation and Recycling 17: $219-226$.

Midmore, D. (1994): Simple hydroponics for food security. ILEIA Newsletter for Low External Input and Sustainable Agriculture, Vol. 10, No. 4. 11-12.

Müller-Sämann, K. M. and Kotschi, J. (1994): Sustaining Growth: Soil Fertility Management in Tropical Smallholdings. Margraf Verlag, Weikerscheim, Germany. pp. 486.

Okigbo, B. N. (1992): Conservation and use of plant germplasm in African traditional agriculture. In: P. Putter (ed.). Safeguarding the Genetic Basis of African Traditional Crops. Proceedings of CTA/IBPGR/KARI/UNEP Seminar. October 5 - 9, 1992. Nairobi, Kenya.
Okonkwo, S. N. C. (1998): The role of biotechnology in enhancing production of underutilised indigenous crops. Paper presented at the meeting of $R \& D$ Team on Indigenous crops and Animals at the National Centre for Genetic Resources and Biotechnology, Moor Plantation, Ibadan. 4-7 May, 1998.

Onwubuya, I.I. (1997): Oil palm (Elaeis guineensis Jacq.) development in Nigeria with particular reference to the south-east agroecolgical zone. An invited paper read at the humid and sub-humid tropics of subSaharan Africa at Concord Hotel, Owerri, Imo State, Nigeria. October 6, 1997.

Stewart, G.A. (1970): Crop productivily in intensive systems. J. Aust. Ins.Agric. Sci. 36: $85-101$.

Villalobos, V. (1996): Brave new technologies. Ceres. The FAO Review No. 153, Vol. 27. No.3. $18-20$. 